\title{
COMPARISON OF HYDROXYETHYL STARCH WITH PLASMA AND DEXTRANS IN SEVERE HAEMODILUTION*
}

\author{
Masuhiko Takaori, M.D., Ph.D., Peter Safar, M.D., and Stephen J. Galla, M.D. $\dagger$
}

IN THE PRESENCE of massive haemorrhage, maintenance of adequate circulating blood volume is mandatory, even though whole blood may be unavailable. The response of dogs to an acute, severe haemodilution to $3 \mathrm{gm}$. per cent haemoglobin with dextran 75 has been studied previously. ${ }^{1}$ Seven of ten animals survived, adapted well, and appeared physically normal after one week. Three main purposes distinguish this paper from previous work:

(1) The evaluation of hydroxyethyl starch (HES) for the treatment of massive haemorrhage. This is a newly developed plasma expander studied by Thompson and Walton ${ }^{2,3}$ and found to be more stable in storage and less expensive to produce than dextran 75 .

(2) Long-term comparison under similar experimental conditions of hydroxyethyl starch with the commonly used blood substitutes-dextran 75, dextran 40 , and plasma.

(3) Determination of the adequacy of oxygen transport to tissues during severe haemodilution, using more pertinent physiological and biochemical measurements than before.

\section{METHODS}

\section{Experimental Procedure}

Male mongrel dogs weighing 12 to $17 \mathrm{~kg}$. were anaesthetized lightly with sodium pentobarbital. The trachea was intubated and attached to a piston ventilator delivering 30 per cent oxygen and 70 per cent nitrogen at a rate and volume sufficient to maintain end-expiratory $\mathrm{PCO}_{2}$ at approximately $40 \mathrm{~mm}$. $\mathrm{Hg}$. Controlled ventilation was facilitated by intermittent injection of a muscle relaxant, gallamine. Aortic and right ventricular pressures and the electrocardiogram were monitored continuously. Cardiac output was measured periodically by a dyedilution technique.,5 The rationale and details of this protocol have been considered previously. ${ }^{1}$ Four treatment groups were established and four dogs were

\footnotetext{
-Department of Anesthesiology, University of Pittsburgh School of Medicine, Pittsburgh, Pennsylvania. Supported by U.S. Army Contract DA-49-193-MD-2160.

fDr. Takaori is Research Fellow, Dr. Safar is Professor and Chairman, and Dr. Galla is Associate Research Professor in the Department of Anesthesiology, University of Pittsburgh School of Medicine. Dr. Takaori's present address is University of Osaka, Osaka, Japan.

$\$$ Hydroxyethyl starch (McGaw Laboratories Division, American Hospital Supply Corp. Evanston, Illinois 60201) is a derivative of amylopectin, a waxy starch containing only branched chains of glycoside molecules. It has the same viscosity in 6 per cent solution as dextran 75 and is resistant to the action of blood amylase. The exact molecular weight is undetermined. For details see: "Artificial Colloidal Agents," National Academy of Sciences (National Research Council), March 1965.
} 
assigned in a random manner to each group. The protocol for each treatment was identical except for the blood substitute administered for haemodilution.

The following blood substitutes were used: $(a)$ dextran $75,6 \%$ in isotonic saline (D-75); (b) dextran 40, 10\% in isotonic saline (D-40); (c) hydroxyethyl starch, $6 \%$ in isotonic saline (HES); $(d)$ homologous plasma, buffered to $\mathrm{pH} 7.4{ }^{\circ}$

After control measurements (Stage I) haemodilution was carried out by withdrawal of arterial blood ( $10 \mathrm{ml} . / \mathrm{kg}$.) every ten minutes, and immediate replacement with an equal amount of blood substitute until the haematocrit had decreased to approximately 10 per cent (10-14 replacements). Measurements were repeated at the end of haemodilution (Stage II), two hours later (Stage III), at 24 hours (Stage IV), and at eight days (Stage V). After the first 24 hours, the animals were allowed food and water ad lib. Stage IV and V measurements were conducted with spontaneous breathing under light anaesthesia with sodium pentobarbital.

\section{Analytical Methods}

Haemoglobin content, ${ }^{6}$ microhaematocrit, arterial $\mathrm{pH}$ and $\mathrm{PCO}_{2}$, arterial and mixed venous oxygen and carbon dioxide content, ${ }^{7}$ and plasma bicarbonate and buffer base ${ }^{8}$ were measured at each stage. Oxygen consumption was calculated as the product of the cardiac index and arterio-venous oxygen content difference. Arterial lactate, pyruvate, and glucose were measured enzymatically. ${ }^{9-11}$ Statistical analyses were performed between stages and between treatment groups, using an analysis of variance.

\section{Survival}

\section{Results}

All four dogs treated with dextran 75 survived the eight-day observation period. Three of those receiving dextran 40 survived, but the other, which did not have a compensatory increase in cardiac output, died four hours after haemodilution. Three of four animals receiving HES survived, but the other died without explanation after five days. All four dogs receiving plasma died, apparently from circulatory collapse, between two and fifty-four hours after haemodilution. Table I presents the mean and standard error of all measurements within each group.

\section{Arterial Haematocrit and Haemoglobin}

Haematocrit values at the end of haemodilution had decreased to 8-9 per cent. Thereafter they rose gradually, reaching 17-19 per cent at eight days. Haematocrit and haemoglobin differed only slightly between treatment groups.

\section{Heart Rate}

Heart rate was essentially unchanged in any group throughout the study, although the values did appear higher than those for normal anaesthetized dogs.

\footnotetext{
* Using sterile techniques, $480 \mathrm{ml}$. of blood was collected from a normal dog into a plastic bag containing $120 \mathrm{ml}$. of ACD solution. The plasma was separated immediately and frozen. Prior to use of the pooled plasma, $\mathrm{pH}$ was adjusted to 7.4 with hydroxymethyl aminomethane (THAM).
} 


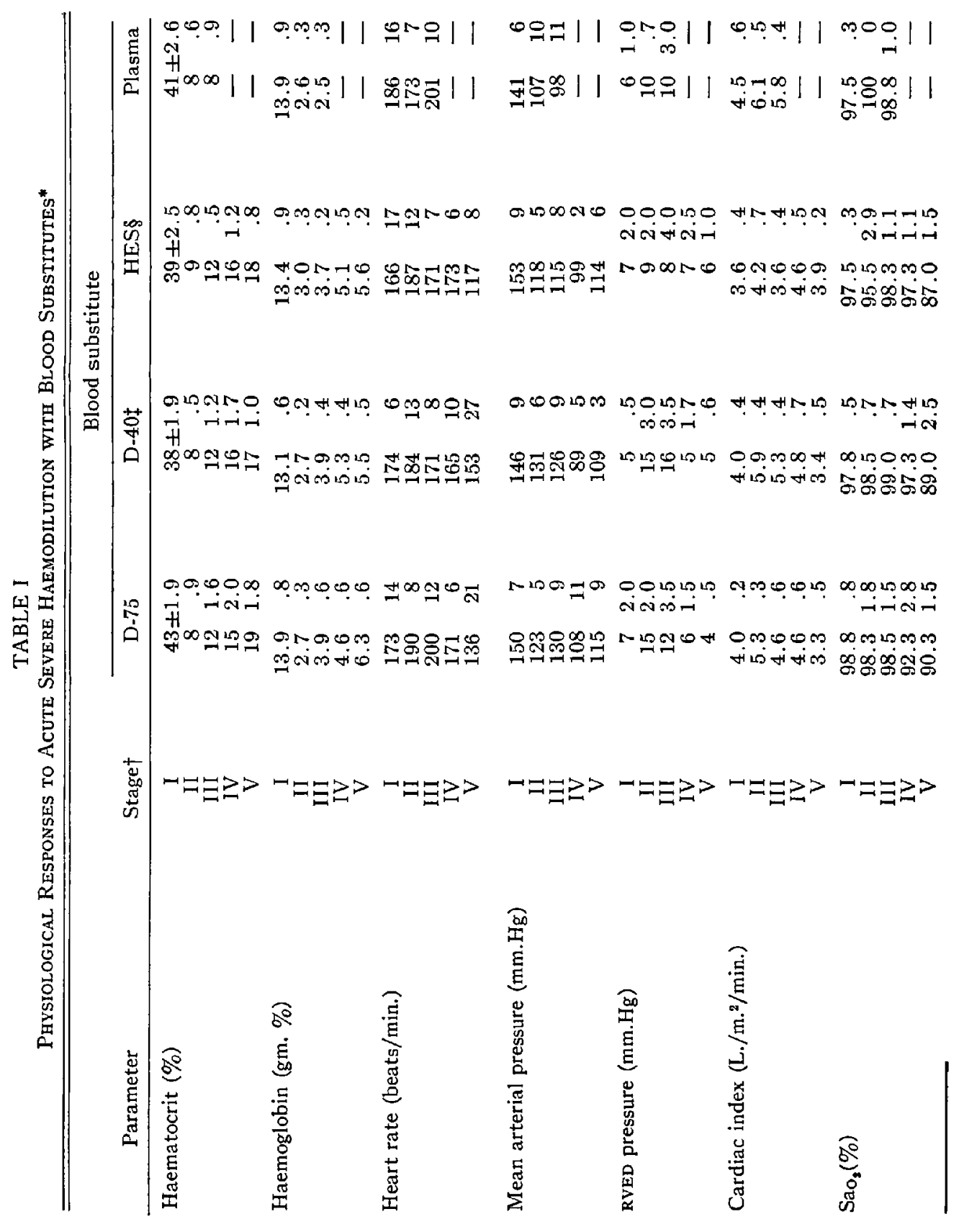




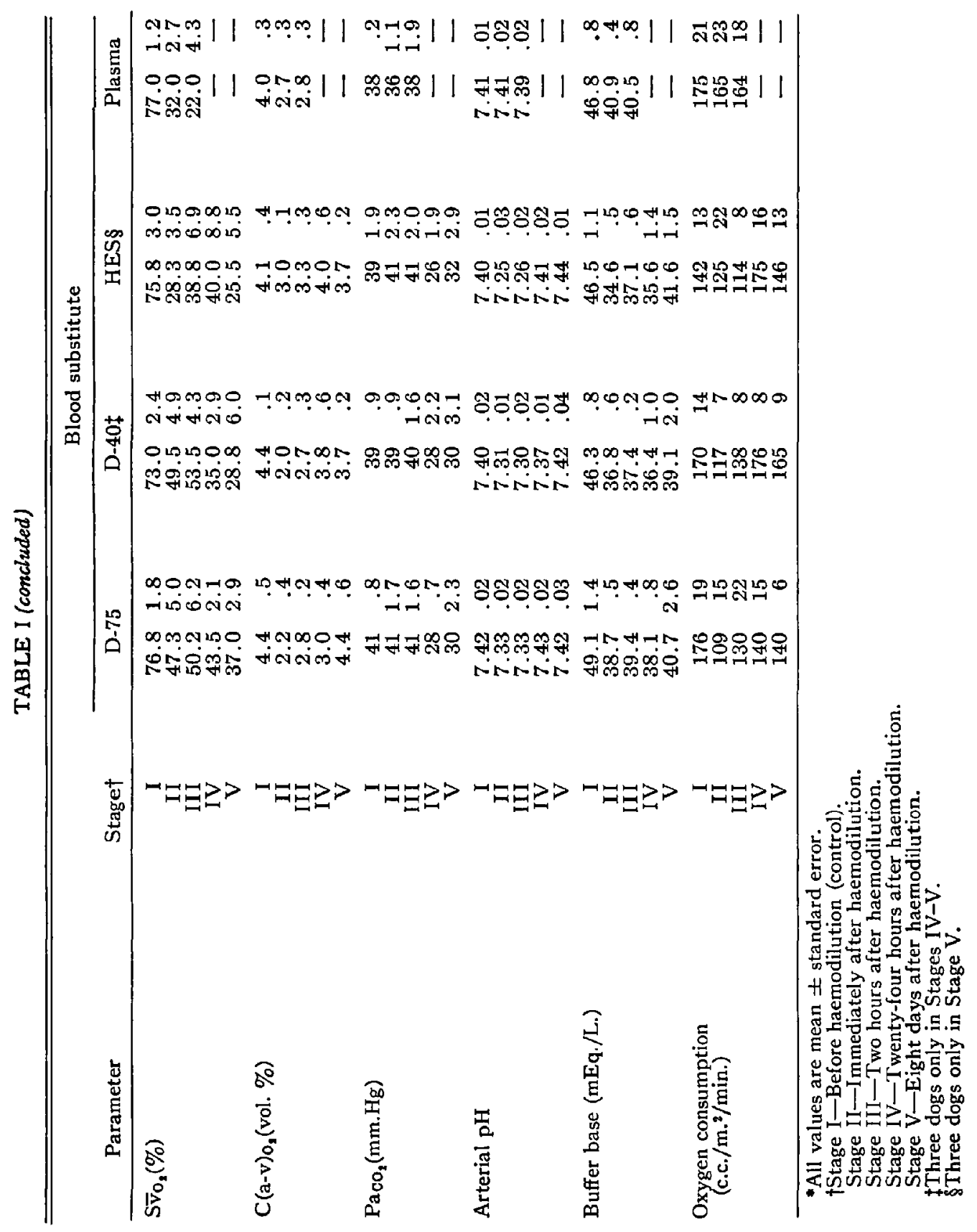




\section{Electrocardiogram}

Except in the plasma group, the QRS vector decreased in all dogs during and following haemodilution. Premature ventricular contractions occurred occasionally in all groups, but were more frequent in dogs receiving dextran 75 .

\section{Mean Arterial Pressure}

Arterial blood pressure decreased slightly in all groups following haemodilution and reached the lowest values 24 hours later. The differences between groups were not significant.

\section{Right Ventricular End-diastolic Pressure}

In all except the HES group, during and immediately after haemodilution there was a significant rise in right ventricular end-diastolic pressure, which returned to control values in 24 hours.

\section{Cardiac Index}

During and immediately after haemodilution the cardiac index rose signifcantly in all except the HES group, where it remained essentially unchanged throughout the study (Fig. 1). Twenty-four hours after haemodilution the cardiac index had returned to control levels and had not changed at eight days. In the plasma group three of four dogs died before 24-hour measurements were made. The other animal, which died 54 hours after haemodilution, had a cardiac index at 24 hours which was 150 per cent of the control value.

\section{Oxygen Saturation}

Arterial oxygen saturation $\left(\mathrm{Sa}_{\mathrm{O}_{2}}\right)$ remained within normal limits in all groups.

\section{CARDIAC INDEX}

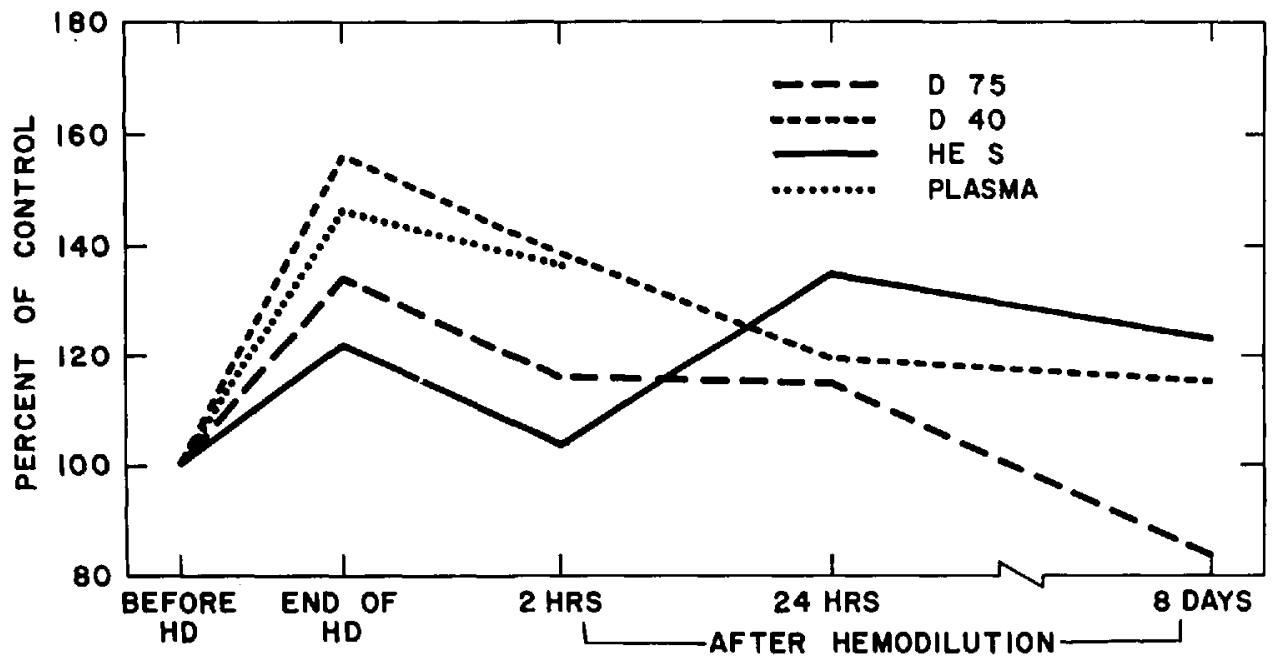

Frgure 1. Changes in mean values of cardiac index following haemodilution to 3 grams per cent haemoglobin. 
The slight decline at 24 hours and at eight days was due probably to ambient air being used during these studies.

At the end of haemodilution mixed venous oxygen saturation $\left(S_{\mathrm{v}_{\mathrm{O}_{2}}}\right)$ had decreased more in the HES and plasma groups than in the dextran groups. The trend was present two hours later; but after 24 hours differences did not exist between the groups, although the $\mathrm{S}_{\mathrm{V}_{2}}{ }_{\mathrm{2}}$ remained low.

\section{Arterio-venous Oxygen Content Difference}

The $\mathrm{C}(\mathrm{a}-\mathrm{v})_{\mathrm{o}_{2}}$ decreased significantly in all groups during and immediately following haemodilution, but was more pronounced in the dextran 40 and dextran 75 groups. After 24 hours $\mathrm{C}(\mathrm{a}-\mathrm{v})_{\mathrm{O}_{2}}$ had returned to initial values.

\section{Carbon Dioxide Tension and $p H$}

Arterial $\mathrm{PCO}_{2}$ remained stable between 36 and $41 \mathrm{~mm}$. $\mathrm{Hg}$ in all groups before, during, and immediately following haemodilution. At 24 hours and at eight days, when the animals were breathing room air spontaneously, $\mathrm{PCO}_{2}$ decreased to a range of $26-32 \mathrm{~mm}$. $\mathrm{Hg}$. In the plasma group $\mathrm{pH}$ values did not change with haemodilution. However, in the dextran and HES groups $\mathrm{pH}$ decreased significantly from control values during haemodilution, but were back to normal at 24 hours.

\section{Buffer Base}

In all the groups buffer base decreased significantly after haemodilution and remained lower than control values throughout the eight-day study period. Serum sodium and potassium concentrations were essentially unaltered.

\section{Oxygen Consumption}

In both of the dextran groups, but not in the plasma or HES groups, oxygen consumption decreased significantly during and two hours after haemodilution. However, at 24 hours it had returned essentially to control values without signifcant differences between groups.

\section{Intermediary Metabolism}

The mean arterial lactic and pyruvic acid concentrations were essentially unchanged in all groups throughout the study period, except for slightly higher values in the plasma group. Undoubtedly the higher values resulted from the infused plasma, which had a mean lactic acid concentration of $13 \mathrm{mg}$. per cent. The arterial glucose content was quite variable and showed no consistent alterations with either time or treatment.

\section{Urinary Output}

In addition to the blood substitute for treatment of haemorrhage, all animals received $300 \mathrm{ml}$. of isotonic saline solution intravenously during the haemodilution period. The mean urinary output during this same period was $105 \mathrm{ml}$. in the dextran 40 group, $200 \mathrm{ml}$. in the dextran 75 group, $220 \mathrm{ml}$. in the HES group, and $335 \mathrm{ml}$. in the plasma group. 


\section{Discussion}

An experimental model, analogous to immediate replacement with a blood substitute in patients, has been designed for the study of haemorrhage. A survey of the literature reveals that the acute anaemias obtained by our haemodilution technique were among the most severe reported with survival. Richet and Brodin $^{12}$ replaced 96 per cent of the total blood volume in dogs with horse serum, but details regarding survival were unavailable. Couvreur and Clement ${ }^{13}$ were unable to obtain survival with serum infusion in dogs following massive haemorrhage.

Am ${ }^{\mathrm{l}} \mathrm{serson}{ }^{14}$ found that cats, rabbits, and dogs tolerated well an acute reduction of haemoglobin without oligaemia. He replaced blood loss with Ringer-Locke's solution containing 12 to $14 \mathrm{gm}$. per cent of free haemoglobin. Death occurred when the haemoglobin concentration was lowered to $3 \mathrm{gm}$. per cent. Takaori and Safar ${ }^{15}$ reported that with a similar degree of haemodilution produced by lactated Ringer's solution (one to 2.5 times the volume of blood removed), but without added colloid, circulatory deterioration occurred because of the loss of fluid from the intravascular space.

Death of the two animals receiving dextran 40 and HES may have been related to their inability to respond to acute haemodilution with a significant increase in cardiac index. Takaori and Safar ${ }^{1}$ found this correlation in studies with dextran 75. We were unable to explain the inability of animals in the plasma group to survive for more than 54 hours, except to emphasize that they apparently died from circulatory collapse. Remington and Baker ${ }^{16}$ infused homologous plasma into healthy dogs, leading to hypotension, urticaria, tissue oedema and hypovolaemia. Hutchison, Freedman, Richard, and Burgen ${ }^{17}$ found that after haemodilution with homologous plasma (but not with autologous), plasma was lost from the circulation. Arterial pressure was maintained better with dextran than with plasma. Wise, Morse, and Allen ${ }^{18}$ were unable to confirm the findings of Hutchison, et al. The type of plasma infused may explain the discrepancy in the above reports. In our experiments any of the following reasons might have contributed to the deaths in the plasma group: $(a)$ vasodilatation due to THAM $^{19}(b)$ loss of plasma from circulation, $(c)$ lowered viscosity of infused plasma due to ACD solution, and (d) a hypersensitivity reaction with histamine release.

The ability of the three colloidal volume expanders to promote survival, and the relative constancy among the parameters studied, attests to their effectiveness in the treatment of haemorrhage. However, some differences occurred which are worthy of further discussion. In the HES group, arterial pressure declined more than in the dextran groups, although there was essentially no change in cardiac index. A lower arterial $\mathrm{pH}$ and reduced plasma expansion, as reflected by the absence of an increase in right ventricular end diastolic pressure, may explain the lack of a compensatory increase of cardiac index with HES.

In general, the observation that changes in cardiac index were inversely related to the arterio-venous oxygen difference suggests that compensation for the acute reduction in arterial oxygen content is mediated by an increased 
cardiac index. The interrelationship of venous oxygen saturation, haemoglobin content, and cardiac index observed in our experiments agreed with the findings of Barratt-Boyes and Wood, ${ }^{20}$ and Murray. ${ }^{21}$ Although the increase in cardiac index following acute, normovolemic anaemia has been demonstrated previously, ${ }_{2}^{1,22,25}$ its mechanism remains obscure. One report suggests that the increase in cardiac index during anaemia is primarily related to the anaemia per se, rather than volume factors. ${ }^{26}$ Numerous investigators ${ }^{27-32}$ have shown that blood volume increases more than expected following the infusion of dextrans. Recent studies in our laboratory indicate that blood volume increases to approximately 130-150 per cent of control values during haemodilution with dextran 40 and HES. ${ }^{33}$

Impaired transport may have been a cause of the reduced oxygen consumption in all but the plasma group during haemodilution, although the reduction was less marked than that observed during oligaemic shock. Whether or not anaerobic metabolism is increased in the presence of the markedly lowered arterial oxygen capacity is questionable. Arterial $\mathrm{pH}$ decreased only slightly in all the groups, and lactate and pyruvate values remained within normal limits. The change in $\mathrm{pH}$ can be explained by the decrease in buffer base concentration resulting from dilution, and by the reduction in the red cell mass. ${ }^{34}$ It is interesting to note that glucose and serum electrolytes were maintained at normal values in the presence of such profound haemodilution.

\section{SUMMARY}

A long-term comparison of hydroxyethyl starch with the commonly used blood substitutes, dextran 75, dextran 40, and buffered, homologous plasma was performed, using a haemodilution technique which clinically simulates the correction of haemorrhage. All animals receiving dextran 75, and three of four animals receiving either dextran 40 or hydroxyethyl starch survived for at least eight days. Only one animal that received buffered plasma survived more than 24 hours. Possible causes of death were discussed. The mechanisms of adaptation to the acute reduction of arterial oxygen content were similar in all groups. Whereas the mean cardiac index and coefficient of oxygen extraction rose, mean arterial blood pressure, oxygen consumption, and venous oxygen saturation declined moderately. Since no evidence of anaerobic metabolism was observed, apparently oxygen delivery to tissues was well maintained. One week following haemodilution most parameters had returned to normal values, although haemoglobin content remained less than 50 per cent of control. Hydroxyethyl starch was as adequate a colloidal substitute as dextran 40 and dextran 75 in its ability to sustain circulatory and metabolic parameters.

\section{RÉSUMÉ}

En présence d'une hémorrhagie, il est de première importance de maintenir un volume sanguin circulant adéquat, même s'il nous est impossible d'obtenir $\mathrm{du}$ sang entier. Pour reproduire une situation clinique semblable, nous avons établi, chez des chiens, une procédure expérimentale qui consistait à retirer du 
sang artériel et à le remplacer par un des quatre substituts du sang, jusqu'à ce que l'on obtienne un taux d'hémoglobine de 3 gr. pour cent au cours d'une période de 100 minutes. Tous les animaux qui ont reçu du dextran 75 ont survécu huit jour alors que, chez les animaux qui avaient reçu du plasma carbonaté, un seul a vécu plus de 24 heures. Trois des quatre chiens qui avaient reçu soit du dextran 40 soit de l' "hydroxyéthyl starch" ont vécu huit jours. L'adaptation à une diminution rapide du taux d'oxygène dans le sang artériel s'est manifestée par l'élévation de l'index cardiaque et, chez tous les groupes, cette élévation a été semblable.

La mort a souvent été accompagnée de l'incapacité d’augmenter lindex cardiaque. Nous n'avons pu observer de façon concluante qu'il s'amorçait un métabolisme anaérobique. Une semaine après l'hémodilution, toutes les données, à l'exception du taux d'hémoglobine, étaient redevenues près de la normale. L' "hydroxyéthyl starch" a maintenu adéquatement les paramètres circulatoires et métaboliques et, sous cet angle là, il est comparable aux dextrans 40 et 75 .

\section{ACKNOWLEDGMENTS}

The authors wish to thank Dr. Lincoln J. Gerende and Dr. Ned G. Maxwell for their assistance, and Dr. M. Roberts and Dr. R. T. Walton for supplying the hydroxyethyl starch.

\section{REFERENCES}

1. Takaori, M. \& Safar, P. Adaptation to Acute, Severe Hemodilution with Dextran 75 in Dogs. A.M.A. Arch. Surg. 92: 743 (1966).

2. Thompson, W. L.; Britton, J. J.; \& Whaton, R. P. Persistence of Starch Derivatives and Dextran when Infused after Hemorrhage. J. Pharmacol. \& Exper. Therap. 136: 125 (1962).

3. Thompson, W. L. \& WaLton, R. P. Circulatory Responses to Intravenous Infusions of Hydroxyethyl Starch Solutions. J. Pharmacol. \& Exper. Therap. 146: 359 (1964).

4. Woon, E. H.; Swan, H. J. C.; \& Helmholz, H. F. Recording and Basic Pattern of Dilution Curves; Normal and Abnormal. Proc. Mayo Clinic 32: 463 (1957).

5. Fox, I. J.; Brooker, L. G. S.; Heseltine, D. W.; Essex, H. E.; \& Wood, E. H. A Tricarbocyanine Dye for Continuous Recording of Dilution Curves in Whole Blood Indifferent of Various Blood Oxygen Saturations. Proc. Mayo Clinic 32: 478 (1957).

6. KING, E. J. \& GrLCHrist, M. Determination of Haemoglobin by Cyanhaematin Methods. Lancet. 253: 201 (1947).

7. VAN SLYKE, D. D. \& NeILL, J. M. Determination of Gases in Blood and Other Solutions by Vacuum Extraction and Manometric Measurement. J. Biol. Chem. 61: 523 (1924).

8. Sncerr, R. B. \& Hasting, A. B. An Improved Clinical Method for the Estimation of Disturbance of the Acid-Base Balance of Human Blood, Medicine. 27: 223 (1948).

9. HoRn, H. D. \& Brüns, F. H. Quantitative Bestimmung von L $(+)$-Milchsäure mit Milchsäuredehydrogenase. Biochem. Biophys. Acta. 21: 378 (1956).

10. Segal, S.; Blatr, A. E.; \& Wyngaarden, J. B. An Enzymatic Spectrophotometric Method for the Determination of Pyruvic Acid in Blood. J. Lab. \& Clin. Med. 48: 137 (1956).

11. Huggett, A. St. G. \& Nixon, D. A. Enzymatic Determination of Blood Glucose. Biochem. J. 66: $12(1957)$.

12. Richet, C. \& Brodin, P. C. R. Acad. Sc. 167: 55 (1917), cited from W. R. Amberson, Blood Substitutes. Biol. Rev. 12: 48 (1937).

13. Counneur, E. \& Clement, H. Sur la Toxicité de l'oxyhémoglobine. Compte Rendu Soc. Biol. 82: 612 (1919). 
14. Amberson, W. R. Blood Substitutes. Biol. Rev. 12: 48 (1937).

15. TAKaORI, M. \& SAFAR, P. Acute, Severe Hemodilution with Lactated Ringer's Solution. Arch. Surg. 94: 67 (1967).

16. Remington, J. W. \& Baker, C. H. Plasma Volume Changes Accompanying Reaction to Infusions of Blood or Plasma. Am. J. Physiol. 197: 193 (1959).

17. Hutchison, J. L.; Freedman, S. O.; Richard, B. A.; \& Burgen, A. S. V. Plasma Volume Expansion and Reaction after Infusion of Autologous and Non-autologous Plasma in Man. J. Lab. Clin. Med. 56: 734 (1960).

18. Wise, W. H.; Morse, M.; \& Alten, J. G. The Physiological Effects of Acute Anemia Produced by the Replacement of Serial Hemorrhages with Dextran, Plasma and Whole Blood. Surg. Forum 8: 18 (1957).

19. Hinshaw, L. B.; Vick, J. A.; Nelson, D. L.; Witters, L. E.; \& Swenson, O. P. Circulatory Responses to a $\mathrm{CO}_{2}$ Buffer Following Lethal Injections of Endotoxin. Am. J. Physiol. 200: 751 (1961).

20. Barratt-Boyes, B. G. \& Wodd, E. H. The Oxygen Saturation of Blood in the Venae Cavae, Right Heart Chambers, and Pulmonary Vessels of Healthy Subjects. J. Lab. \& Clin. Med. 50: 93 (1957).

21. Murray, J. F. Venous Oxygenation and Circulatory Response to Oxygen Inhalation in Acute Anemia. Am. J. Physiol. 207: 228 (1964).

22. Wilson, J. S.; Estes, E. H., Jr.; Doyle, J. T.; Bloom, W. L.; \& Warren, J. V. The Use of Dextran in the Treatment of Blood Loss and Shock. Am. J. Med. Sci. 223: 364 (1952).

23. Sunahara, F. A. \& Beck, L. Cardiovascular Effect of Acutely Produced Anemia. Am. J. Physiol. 176: 139 (1954).

24. Fowler, N. O.; Franch, R. H.; \& Bloom, W. L. Hemodynamic Effects of Anemia with and without Plasma Volume Expansion. Circ. Res. 4: 319 (1956).

25. Murray, J. F.; Gold, P.; \& Johnson, B. L., JR. Systemic Oxygen Transport in Induced Normovolemic Anemia and Polycythemia. Am. J. Physiol. 203: 730 (1962).

26. Fowler, N. O.; Bloom, W. L.; \& Ward, J. A. Hemodynamic Effects of Hypervolemia with and without Anemia. Circ. Res. 6: 163 (1958).

27. Turner, F. P.; Butler, B. C.; Smith, M. E.; \& Scudder, J. Dextran: An Experimental Plasma Substitute. Surg. Gynec. \& Obst. 88: 661 (1949).

28. Geltn, L. E.; Sölvelt, L.; \& Zederfeldt, B. The Plasma Volume Expanding Effect of Low Viscous Dextran and Macrodex. Acta Chir. Scandinav. 122: 309 (1961).

29. Meyer, L. M.; Berlin, N. I.; Hyde, G. M.; Parsons, R. J.; \& Whittington, B. Changes in Blood Volume Following Administration of Dextran Determined by ${ }^{32}$-labeled Red Cells. Surg. Gynec. \& Obst. 94: 712 (1952).

30. Pirant, C. L.; Juster, R.; Froeb, H. G.; Consolazio, C. F.; \& Ingraham, R. C. Use of Dextran in Hemorrhagic Shock. J. Appl. Physiol. 8: 193 (1955).

31. Wasserman, K. \& Mayerson, H. S. Relative Importance of Dextran Molecular Size in Plasma Volume Expansion. Am. J. Physiol. 176: 104 (1954).

32. AhNefeld, F. W.; Halmagyi, M. \& Ueberla, K. Untersuchungen zur Bewertung kolloidaler Volumenersatzmittel. Anaesthesist. 14: 10 (1965).

33. TAKaOru, M. \& SaFar, P. Body Fluid Compartment Changes after Hemorrhage Treated with LMW Dextran and HE Starch. Fed. Proc. 25: 698 (1966).

34. Rouchton, F. J. W. Some Recent Work on the Chemistry of Carbon Dioxide Transport by the Blood. Harvey Lectures. 39: 96 (1943-44). 